\author{
ADRIAN LORETAN-SALADIN \\ University of Lucerne, Switzerland \\ (D) https://orcid.org/0000-0002-7677-9706
}

\title{
Swiss Synodality after the Second Vatican Council
}

\begin{abstract}
Quod omnes tangit, ab omnibus tractari et approbari debent. (Cardinal Congar) The canonists have been developing the rule of law of Western Europe.

After there had been much debate (Acts 15:7), they decided together with the Holy Spirit. The Apostolic Nuncio gave the permission for lay persons (including women) to participate at the Synod. Synod ' 72 is a process involving seven synods of local Churches in Switzerland. As an instrument of "processing" Vatican II, Synod '72 discussed implementation options like Ecclesiastical Offices of the local Church. (LG 33; Paul VI's Ministeria quaedam; John Paul II's Christifedles laici; c. 228 CIC 1983). The tradition of shared decision-making of the baptised was been activated.
\end{abstract}

Keywords: participants of the Synods of the local Churches, local Ecclesiastical Offices of lay ministers and the deacons, democracy, rule of law, western legal tradition, women in the decision-making process

\section{The Synod '72}

In Switzerland, "the Synod '72" since the very beginning has been understood as an instrument of "processing" Vatican II. The Swiss Bishops' Conference decided to hold coordinated diocesan synods. Bishop John Vonderach was the first to mention a diocesan synod in 1966. However, reactions to the episcopal announcement were very scarce. The episcopal vicars Alois Sustar (Chur), Ivo Führer (St. Gallen), and Otto Wüst (Basel) suggested to their bishops that a synod of the German-speaking dioceses should be organised. Not only the German-speaking bishops wanted to participate, but also the French- and Italian-speaking bishops were in favour. For this reason, the Swiss Bishops' Conference (hereinaf- 
ter: SBC) was able to decide that diocesan synods should be implemented in coordination throughout Switzerland. They would begin in 1972; this explains the term Synod ' 72 .

Synod ' 72 is the convocation of seven synods of local Churches in Switzerland after Vatican II between 1972-1975. Six dioceses and one territorial abbey coordinated their synods. Thus, it was not a national synod. This process yielded two kinds of documents. On the one hand, there are decisions which are legally binding due to being approved by respective bishops. On the other hand, there are documents which are coordinated throughout Switzerland. However, the latter kind of texts could not be ratified. The decision of the synods is not legally binding until every single bishop gives his consent. If the bishops do not give their consent, the text of Synod ' 72 has the character of a recommendation for the Swiss Bishops' Conference.

\section{Ecclesiastical Offices of the Local Church}

Motivated by Vatican II, the laity were eager to study theology. Thus, the Synod '72, as an instrument of processing Vatican II's resolutions, discussed implementation options: "Furthermore, it is to be hoped that many of the laity will receive a sufficient formation in the sacred sciences and that some will dedicate themselves professionally to these studies, developing and deepening them by their own labors. In order that they may fulfill their function, let it be recognized that all the faithful, whether clerics or laity, possess a lawful freedom of inquiry, freedom of thought and of expressing their mind with humility and fortitude in those matters on which they enjoy competence" (GS 16).

At the beginning of the Synod, the Motu proprio "Ministeria Quaedam" by Pope Paul VI encouraged the episcopal conferences to apply for further ecclesiastical offices of the local Church. "In addition to the offices universal in the Latin Church, the conferences of bishops may request others of the Apostolic See, if they judge the establishment of such offices in their region to be necessary or very useful because of special reasons. [...] It is in accordance with the reality itself and with the contemporary outlook that the above-mentioned ministries should no longer be called minor orders; their conferral will not be called ordination, but institution."

${ }^{1}$ Paul VI: Apostolic Letter given Motu Proprio "Ministeria Quaedam": On first tonsure, minor orders, and the subdiaconate. Rome 1972, n. 5-6. Available online at: 
The term institutio has been incorporated into the legal language of the dioceses of Basel, St Gallen and Chur for persons who are ready to work life long in a pastoral office for the local Church. And some years later the Code of John Paul II confirmed this tradition. "Qualified lay persons are capable of assuming from their sacred pastors those ecclesiastical offices and functions which they are able to exercise in accord with the prescriptions of law" (c. 228 \$ 1 CIC 1983). They are also "capable of assisting the pastors of the Church as experts or advisors; they can do so even in councils, in accord with the norm of law" (c. 228 \$2). The Regulae Iuris had integrated this as " "what touches all must be approved by all', though not in the sense of democratizing decisions in the Church."

John Paul II continued this tradition when he applied all Latin terms of ecclesiastical ministry to lay people in his Post-synodal Apostolic Exhortation "Christifideles laici" No. 23: Varia ministeria, officia et munera, quae christifideles possunt legitime sustinere in liturgia, in fidei transmissione et in structuris pastoralibus Ecclesiae, exercenda erunt ratione quadam cum eorum specifica vocatione laicali concordi, quae alia erit ab illa sacrorum ministeria propria. (The various ministries, offices and roles that the lay faithful can legitimately fulfill in the liturgy, in the transmission of the faith, and in the pastoral structure of the Church, ought to be exercised in conformity to their specific lay vocation, which is different from that of the sacred ministry).

In his commentaries about the Synod 72, Manfred Belok "is amazed at the openness and ease with which the women and men of the Synod [...] presented the theme [ministries and church offices] without any prohibition on thinking. This Helvetian and deeply Christian sincerity still impresses and convinces today." 3 He remembers a word of the Doctor of the Church Teresa of Avila (1515-1582): "I accuse our time that it repels strong and good to all talented minds just because they are women." 4

The Synod '72 pleads, however, for an opening of the admission conditions to the consecrated offices which we see in our time in the texts of Pope Francis: "I dream of a 'missionary option', that is, a missionary impulse capable of transforming everything, so that the Church's cus-

https://w2.vatican.va/content/paul-vi/la/motu_proprio/documents/hf_p-vi_motu-pro prio_19720815_ministeria-quaedam.html (accessed 9.09.2019).

2 J. A. Coriden, Th. J. Green, D. E. Heintschel: The Code of Canon Law. A Text and Commentary. New York 1985, p. 165.

${ }^{3}$ M. Bецок: "Die Synode 72 Schweiz: Das kirchliche Dienstamt und die Anfänge zweier ,Laien'-Ämter." In: Die Kirchenbilder der Synoden. Zur Umsetzung konziliarer Ekklesiologie in teilkirchlichen Strukturen [Europas Synoden nach dem Zweiten Vatikanischen Konzil, 3]. Eds. J. Schmiedl, R. Walz. Freiburg i.Br. 2015, p. 138.

${ }^{4}$ Teresa von Avila: Camino de Perfeccion. Manuskript, Escorial 4,1. 
toms, ways of doing things, times and schedules, language and structures can be suitably channelled for the evangelization of today's world rather than for its self-preservation. The renewal of structures demanded by pastoral conversion can only be understood in this light: as part of an effort to make them more mission-oriented." 5

Like the Synod '72, Pope Francis today emphasises the importance of the local Church and its institutions: "It is not advisable for the Pope to take the place of local Bishops in the discernment of every issue which arises in their territory. In this sense, I am conscious of the need to promote a sound 'decentralization'."' The Synod '72 took this path in anticipatory obedience. The lay ministries introduced by the Synod ' 72 should be developed in a decentralised manner.

The Second Vatican Coucil also proposed this path of decentralisation in the introduction of the diaconate for viri probati: "It pertains to the competent territorial bodies of bishops, of one kind or another, with the approval of the Supreme Pontiff, to decide whether and where it is opportune for such deacons to be established for the care of souls. With the consent of the Roman Pontiff, this diaconate can, in the future, be conferred upon men of more mature age, even upon those living in the married state" (LG 29).

\section{Is the Synod '72 a parliament?}

The faithful have been asking: How should the Synod ' 72 be understood? Before the revival of the synodality in the Church, a professor of canon law in Chur told the following story. "You can embarrass the bishop badly if you inquire him by the statute, the diocesan synod. [...] Such a thing does not exist, and a diocesan synod has never taken place since the Council of Trent (1545-1563), although this would have encouraged the bishops." An annual diocesan synod was scheduled in Decretum Gratiani (D.18, c. 16) and in the Council of Trent. ${ }^{8}$ The Code of 1917 envis-

${ }^{5}$ Francis: Apostolic Exhortation “Evangelii Gaudium”, Rome 2013, n. 27. Available online at: http://w2.vatican.va/content/francesco/it/apost_exhortations/documents/papafrancesco_esortazione-ap_20131124_evangelii-gaudium.html. Accessed 09.09.2019.

${ }^{6}$ Ibidem, n. 16.

7 A. Gasser: Das Kirchenvolk redet mit. Die Synode 72 in der Diözese Chur. Zürich 2005, 9 .

${ }^{8}$ Council of Trent: Sessio XXIV: De reformatione, c. 2. In: Conciliorum Oecumenicorum Decreta, p. 737. 
aged a diocesan synod every ten years (c. 356). ${ }^{9}$

However, the Benedict's Rule, which was formative for the law tradition of the Latin Church, requires: "As often as important questions have to be dealt with in the monastery, the abbot should convene the whole community [...]. When he has heard the advice of the brethren, let him ponder the matter and then do what he thinks best" (RB III, 1-2). For the hearings of the brethren, the monasteries built chapter houses. In the interpretation of these lines of the Benedict's Rule, the Cistercians ${ }^{10}$ developed a new term and a new institution called "Parliamentum," 11 which is still in use, not only in the British House of Commons. In their search for the minimum amount of exercise of power, the Cistercians develop the concept of Parliament. "Blessed are the meek, for they shall inherit the earth" (Mt 5.5).

At the beginning of this process you find St. Benedict's advice: "Listen, $\mathrm{O}$ my son, to the teachings of your master, and turn to them with the ear of your heart" (RB, Prologue, 1). A philosopher recently held her inaugural lecture at the University of Zurich with the title: "To listen, a subversive act."12 The abbots who really listened to their brethren developed the fundament of democracy: the parliament. That was indeed a subversive act, reported this philosopher with the name "Abbt", which means Abbot. When the Roman Empire collapsed, the Church could not continue her tradition of bishop's elections because there was no rule of law which could guarantee the legitimacy of the elections. However, the

${ }^{9}$ Cf. K. Mörsdorf: "Das synodale Element der Kirchenverfassung im Lichte des Zweiten Vatikanischen Konzils." In: Volk Gottes. Zum Kirchenverständnis der katholischen, evangelischen und anglikanischen Theologie. Festgabe für J. Höfer. Eds. R. BÄUmER, H. Dolch. Freiburg i.Br., Basel, Wien 1967, p. 568; E. Corecco: "Die synodale Aktivität im Aufbau der katholischen Kirche der Vereinigten Staaten von Amerika." Archiv für katholisches Kirchenrecht 137 (1968), pp. 44-46.

10 Cistercians are monks or nuns of an order founded in 1098 as a stricter branch of the Benedictines. The monks are now divided into two observances, the strict observance, whose adherents are known popularly as Trappists, and the common observance, which has certain relaxations.

${ }^{11}$ J. J. Lozano: Kastilien. Eine spirituelle Reise durch das Herz Spaniens. Freiburg Schweiz 2005, pp. 81-91. There is some Cistercian democratic practice in the practice of the British Parliament, e.g. the "pedibus ire in sententiam", where you vote by leaving the conference room. Ibidem, p. 82.

12 Сн. Аввт: Antrittsvorlesung als Privatdozentin an der Philosophischen Fakultät der Universität Zürich 11.12.2017. Available online at: "Zuhören ein subversiver Akt" http://www.ifk.ac.at/index.php/blog-detail/zuhoeren-ein-subversiver-akt-christine-abbt -antrittsvorlesung-als-privatdozentin-an-der-philosophischen-fakultaet-der-universita. html (accessed 9.09.2019). 
tradition survived in the monasteries, according to Yves Cardinal Congar. ${ }^{13}$

As we have seen, the term parliament is an invention of religious law. Why should it not be applicable to the Synod '72? The German Cardinals, Karl Lehmann und Josef Ratzinger, consider this possibility in their publications. $^{14}$

\section{Synodality and the rule of law}

We construe the "rule of law" to mean that a body of rules exists, one that is defined and enforced well enough to constrain arbitrary governmental actions, and that government itself has well defined and enforced civil and criminal rules to govern social interactions. The Church's wealth flowed in substantial part from monastic estates, whose heightened productivity likely resulted from cooperative behaviour encouraged by the shared beliefs and social norms within the monastery.

In the first centuries of the first millennium, there was a notable difference between the structure of the Church and the legal structure of the State. The parliamentary structure of the synods of the Roman Catholic Church was totally different from the hierarchical structure of the Roman Empire. ${ }^{15}$ The Christians believed that they would find their way in synods in collaboration with the Holy Spirit. "After there had been much debate" (Acts 15:7) they decided together with the Holy Spirit: "For it has seemed good to the Holy Spirit and to us to lay on you no greater burden than these requirements" (Acts 15: 28).

${ }^{13}$ See Y. Congar: "Quod omnes tangit, ab omnibus tractari et approbari debent." Revue historique de droit français et étranger 35 (1958), pp. 210-259. Cf. For a critique of this article by Congar, see: : P. Huser: Vernunft und Herrschaft. Die kanonischen Rechtsquellen als Grundlage natur- und völkerrechtlicher Argumentation im zweiten Prinzip des Traktates „Principia quaedam“ des Bartolomé de Las Casas [ReligionsRecht im Dialog, 11]. Zürich 2011, p. 97.

${ }^{14}$ K. Lehmann: "Die Theologie des Bischofsamtes nach dem Zweiten Vatikanischen Konzil und ihre Bedeutung für synodale Prozesse" In: Die Kirchenbilder der Synoden. Zur Umsetzung konziliarer Ekklesiologie in teilkirchlichen Strukturen [Europas Synoden nach dem Zweiten Vatikanischen Konzil, 3]. Eds. J. Schmiedl, R. Walz. Freiburg i.Br. 2015, p. 33. Cf. J. Ratzinger, H. Maier: Demokratie in der Kirche. Möglichkeiten und Grenzen. Limburg $2005^{2}$.

${ }^{15}$ Cf. L. Siedentop: Inventing the Individual. The Origins of Western Liberalism. London 2014. 
This tradition of synods was in use in the monastic orders as well. If there is any deeper connection between the "rule of St. Benedict" and "the rule of Law," then it must be found in further research. To live under a Rule is the main concept of Benedict's Rule. Gratian, the great founder of the science of canon law "concluded that, as a matter of natural law, princes are bound by and shall live according to their laws. The theory that customs must yield to natural law was one of the greatest achievements of the canonists."16 The Harvard Professor Harold J. Berman found out that "in the twelfth century the canonists and Romanists of Western Europe combined the Greek capacity for philosophy with the Roman capacity for law. In addition, they deepened the earlier concepts of reason and equity by adding to them the Judaic and Christian concept of conscience, which they related to mercy and love." 17 The Idea of Natural Rights was developed throughout the centuries. According to the teaching of John XXIII encyclical Pacem in terries, "natural rights and natural law are both derived, not from some vision of cosmic nature, but from our perception of human nature as 'endowed with intelligence and free will'. [...] Such ideas are not new. The popes of our age, who have embraced so enthusiastically the idea of natural rights, after their predecessors condemned it for many years as an irreligious, Enlightenment aberration, have been returning, unwittingly perhaps, to a tradition rooted in the Christian jurisprudence and philosophy of the Middle Ages. [...] But the appeal to natural rights became more prominent than ever in the political discourse of the eighteenth century. [...] like the American Declaration of Independence or the French Declaration of the Rights of Man and the Citizen. In fact, though, this central concept of Western political theory first grew into existence almost imperceptibly in the obscure glosses of the medieval jurists. One might say that, in the works of the early Decretists, a distinctive mutation of thought and language occurred which gave rise to a whole new species of ideas, the species of natural rights theories." 18 Following Harold J. Berman, the canonists have been developing the rule of law. The medieval Roman Catholic Church created the institutions that generated the rule of law in Western Europe. This fact is not yet well enough known in the canonist literature.

Besides canon law, medieval theology was also decisive for the formation of the western legal tradition of synodality, which lead in the 18th century to democracy. Harold J. Berman concludes that "the history of

${ }^{16}$ H. J. Berman: Law and Revolution. The Formation of the Western Legal Tradition. Cambridge 1983, p. 145.

17 Ibidem, p. 146.

18 B. Tierney: The Idea of Natural Rights, Studies on Natural Rights, Natural Law, and Church Law 1150-1625. Cambridge, Mass. 1997, pp. 343-344. 
Western law, and especially of its origins, reveals its rootedness in the deepest beliefs and emotions of a people. Without the fear of purgatory and the hope of the Last Judgment [Mt 25, 31-46], the Western legal tradition could not have come into being." ${ }^{19}$ So purgatory was an important idea for democracy. "Purgatory is a Christian democracy where proportional equality of punishment is justly meted out to princes and popes no less than serfs and thieves according to the gravity of their sins." 20

The principles of constitutionalism are theoretically refined and instituted in canon and secular law systems during the Papal Revolution. ${ }^{21}$ The term is better known amongst the theologians as the Gregorian Reform.

"On the other hand, the law rests in some sense on the will or consent of the community or citizen-body, since reason and liberty are natural attributes of all human beings as bearers of the image of God, and since the community is composed of persons who are both Christians and universally sinners, so that none is naturally so fit through superiority or perfection as to rule others but by their consent."22 For Berman, western jurisprudence is a secularized theology that no longer knows its theological presuppositions.

\section{Participants of the Synod '72}

Participants of the diocesan synods have been the entire people of God, including lay persons. But in the 13th and 14th centuries, they were not participating anymore. ${ }^{23}$ This is why the CIC 1917 (c. 358) understood the diocesan synod as a purely clerical assembly. ${ }^{24}$

${ }^{19}$ H. J. Berman: Law and Revolution..., p. 558.

${ }^{20}$ Ibidem, p. 171.

${ }^{21}$ Ibidem, p. 9.

22 Ibidem, p. 184.

23 Cf. W. ReEs: «Synoden und Konzile. Geschichtliche Entwicklung und Rechtsbestimmungen in den kirchlichen Gesetzbüchern von 1917 und von 1983." In: Unverbindliche Beratung oder kollegiale Steuerung? Kirchenrechtliche Überlegungen zu synodalen Vorgängen [Europas Synoden nach dem Zweiten Vatikanischen Konzil, 2]. Eds. W. Rees, J. SChMiedl. Freiburg i.Br. 2014, p. 18.

${ }^{24}$ Can $358 \$ 1$. Ad Synodum vocandi sunt ad eamque venire debent:

$1^{\circ}$ Vicarius Generalis;

$2^{\circ}$ Canonici ecclesiae cathedralis aut consultores dioecesani;

$3^{\circ}$ Rector Seminarii dioecesani saltem maioris;

$4^{\circ}$ Vicarii foranei;

$5^{\circ}$ Deputatus uniuscuiusque collegialis ecclesiae a Capitulo eiusdem ecclesiae e gremio eligendus; 
However, after the ecclesiology of the Second Vatican Council's Lumen Gentium, it was no longer conceivable to celebrate a synod without all the people of God. ${ }^{25}$ The bishops and the territorial abbot did not want to be deterred by the law. They asked the Apostolic See for dispensation of Canon 358. The Apostolic nuncio replied within four days and gave them permission for lay people to participate at the Synod '72. ${ }^{26}$ The Synod 72 was proceeding at a time when the Church was debating the legal implementation of the theology of the Second Vatican Council.

Some years after, Pope John Paul II went so far as to demand even the participation of women at all levels, including in decision-making processes: "It is therefore urgently necessary to take certain concrete steps, beginning by providing room for women to participate in different fields and at all levels, including decision-making processes, above all in matters which concern women themselves. [...] In this regard, the history of spirituality owes much to saints such as Teresa of Jesus and Catherine of Siena, the first two women to be given the title 'Doctor of the Church', and to so many other mystics for their exploration of the mystery of God and their analysis of his action in believers!" 27

$6^{\circ}$ Parochi civitatis in qua Synodus celebratur;

$7^{\circ}$ Unus saltem parochus ex unoquoque vicariatu foraneo eligendus ab omnibus qui curam animarum actu inibi habeant; parochus autem electus debet pro tempore absentiae vicarium substitutum sibi sufficere ad normam can. 465 , 4 ;

$8^{\circ}$ Abbates de regimine et unus e Superioribus cuiusque religionis clericalis qui in dioecesi commorentur, designatus a Superiore provinciali, nisi domus provincialis sit in dioecesi et Superior provincialis interesse ipse maluerit.

$\S 2$. Episcopus, si opportunum iudicaverit, potest ad Synodum vocare alios quoque et etiam omnes canonicos, parochos, Superiores religiosos, imo et singulos suae dioecesis saeculares sacerdotes, iis tamen exceptis qui necessarii sunt ne in paroeciis animarum cura desit; invitati autem ius suffragii in omnibus habent, perinde ac ceteri, nisi Episcopus in invitatione aliud expresse caverit. Cf. K. MörSDORF: Lehrbuch des Kirchenrechts aufgrund des Codex Iuris Canonici. Begründet von Edward Eichmann, fortgeführt von Klaus Mörsdorf. Bd. 1. Paderborn 1991'13, pp. 424-425.

${ }^{25}$ P. V. Aimone: "The Participation of Laypeople to the Diocesan Synods Immediately after Vatican II (1966-1983), particularly in the Swiss Local Church.” In: Synod and Synodality. Theology, History, Canon Law and Ecumenism in New Contact. International Colloquium, Bruges 2003 [Christianity and History, 1]. Eds. A. Melloni, S. SCATENA. Münster 2005, pp. 677-702.

${ }^{26}$ Cf. M. Ries: "Auf der Suche nach Ausgleich. Die Schweizer Synode 72." In: Nationalsynoden nach dem Zweiten Vatikanischen Konzil. Rechtliche Grundlagen und öffentliche Meinung [Theologische Berichte, XXXV]. Ed. J. SchmIEDL. Freiburg, Schweiz 2013, p. 107.

27 John Paul II: Post-synodal Apostolic Exhortation "Vita consecrata”. Rome 1996, n. 58. Available online at: http://w2.vatican.va/content/john-paul-ii/en/apost_exhortations/documents/hf_jp-ii_exh_25031996_vita-consecrata.html (accessed 9.09.2019). 
The people of God (Liber II de Populo Dei CIC 1983) will find their way to the future with the Holy Spirit, as it began with a tradition of synodality (Acts 15:28) when "there had been much debate" (Acts 15:7).

The Synod '72 paved the way into the future: "If ecclesiastical talk wants to be taken seriously, it needs to find the concrete situation of thepeople mentioned reference. A church that merely answers problems of the past would be itself superfluous." 28

${ }^{28}$ Formulierung der Diözesansynode Basel, XII, 4.1.2. (Synode 72. Diözese Basel, Gesamtband, Solothurn 1978, zu beziehen bei Pastoralstelle des Bistums Basel, Baselstrasse 58, 4500 Solothurn).

\section{Bibliography}

Аввт Сн.: Antrittsvorlesung als Privatdozentin an der Philosophischen Fakultät der Universität Zürich 11.12.2017. Available online at: http://www.ifk.ac.at/ index.php/blog-detail/zuhoeren-ein-subversiver-akt-christine-abbt-antritts vorlesung-als-privatdozentin-an-der-philosophischen-fakultaet-der-univer sita.html. Accessed 09.09.2019.

Aimone P. V.: The Participation of Laypeople to the Diocesan Synods Immediately after Vatican II (1966-1983), particularly in the Swiss Local Church. In: Synod and Synodality. Theology, History, Canon Law and Ecumenism in New Contact. International Colloquium, Bruges 2003 [Christianity and History, 1], Eds. A. Melloni, S. Scatena. Münster 2005, pp. 677-702.

Belok M.: Die Synode 72 Schweiz: Das kirchliche Dienstamt und die Anfänge zweier ,Laien'-Ämter. In: Die Kirchenbilder der Synoden. Zur Umsetzung konziliarer Ekklesiologie in teilkirchlichen Strukturen [Europas Synoden nach dem Zweiten Vatikanischen Konzil, 3]. Eds. J. SchmiedL, R. Walz. Freiburg i.Br. 2015, pp. 138-164.

Berman H. J.: Law and Revolution. The Formation of the Western Legal Tradition, The President and the Fellows of Harvard College. Cambridge 1983.

Code of Canon Law (CIC/1917).

Congar Y.: Quod omnes tangit, ab omnibus tractari et approbari debent. "Revue historique de droit français et étranger" 35 (1958), pp. 210-259.

Conecco E.: Die synodale Aktivität im Aufbau der katholischen Kirche der Vereinigten Staaten von Amerika. "Archiv für katholisches Kirchenrecht" 137 (1968), pp. 38-94.

Coriden J. A., Green Th. J., Heintschel D. E.: The Code of Canon Law. A Text and Commentary. New York 1985. 
Council of Trent: Sessio XXIV: De reformatione, c. 2. In: Conciliorum Oecumenicorum Decreta, p. 737.

FrancIs: Apostolic Exhortation "Evangelii gaudium”, Rome 2013. Available online at: http://w2.vatican.va/content/francesco/it/apost_exhortations/docu ments/papa-francesco_esortazione-ap_20131124_evangelii-gaudium.html. Accessed 09.09.2019.

Huser P.: Vernunft und Herrschaft. Die kanonischen Rechtsquellen als Grundlage natur- und völkerrechtlicher Argumentation im zweiten Prinzip des Traktates „Principia quaedam“ des Bartolomé de Las Casas [ReligionsRecht im Dialog, 11]. Zürich 2011.

Lehmann K.: Die Theologie des Bischofsamtes nach dem Zweiten Vatikanischen Konzil und ihre Bedeutung für synodale Prozesse. In: Die Kirchenbilder der Synoden. Zur Umsetzung konziliarer Ekklesiologie in teilkirchlichen Strukturen [Europas Synoden nach dem Zweiten Vatikanischen Konzil, 3]. Eds. J. Schmiedu, R. Walz. Freiburg i.Br. 2015, pp. 11-34.

Lozano J. J.: Kastilien. Eine spirituelle Reise durch das Herz Spaniens. Freiburg Schweiz 2005.

MörsDorf K.: Das synodale Element der Kirchenverfassung im Lichte des Zweiten Vatikanischen Konzils. In: Volk Gottes. Zum Kirchenverständnis der katholischen, evangelischen und anglikanischen Theologie. Festgabe für J. Höfer. Eds. R. Bäumer, H. Dolch. Freiburg i.Br., Basel, Wien 1967, pp. 568-584.

Mörsdorf K.: Lehrbuch des Kirchenrechts aufgrund des Codex Iuris Canonici. Begründet von Edward Eichmann, fortgeführt von Klaus Mörsdorf. Bd. 1. Paderborn 1991.

John Paul II: Post-synodal Apostolic Exhortation "Vita consecrata", Rome 1996. Available online at: http://w2.vatican.va/content/john-paul-ii/en/apost_exho rtations/documents/hf_jp-ii_exh_25031996_vita-consecrata.html. Accessed 09.09.2019.

Paul VI: Apostolic Letter given Motu Proprio “Ministeria Quaedam”: On first tonsure, minor orders, and the subdiaconate. Rome 1972. Available online at: https://w2.vatican.va/content/paul-vi/la/motu_proprio/documents/hf_p-vi_ motu-proprio_19720815_ministeria-quaedam.html. Accessed 09.09.2019.

Ratzinger J., Maier H.: Demokratie in der Kirche. Möglichkeiten und Grenzen. Limburg $2005^{2}$.

ReEs W.: Synoden und Konzile. Geschichtliche Entwicklung und Rechtsbestimmungen in den kirchlichen Gesetzbüchern von 1917 und von 1983. In: Unverbindliche Beratung oder kollegiale Steuerung? Kirchenrechtliche Überlegungen zu synodalen Vorgängen [Europas Synoden nach dem Zweiten Vatikanischen Konzil, 2]. Eds. W. Rees, J. Schmiedl. Freiburg i.Br. 2014, pp. 10—67.

Ries M.: Auf der Suche nach Ausgleich. Die Schweizer Synode 72. In: Nationalsynoden nach dem Zweiten Vatikanischen Konzil. Rechtliche Grundlagen und öffentliche Meinung [Theologische Berichte, XXXV]. Ed. J. SchmiEdL. Freiburg Schweiz 2013, pp. 101-115.

Siedentop L.: Inventing the Individual. The Origins of Western Liberalism, by Allen Lane an imprint of Penguin Books. London 2014. 
Synode 72. Diözese Basel, Gesamtband. Solothurn 1978.

Teresa von Avila: Camino de perfección. Manuskript.

Tierney B.: The Idea of Natural Rights, Studies on Natural Rights, Natural Law, and Church Law 1150-1625 [Emory University studies in law and religion, 5]. Michigan Cambridge 1997, pp. 343-344.

Adrian Loretan-SaLAdin

La synodalité suisse après le Concile Vatican II

Résumé

Le Synode '72 est un processus de sept synodes d’Églises locales en Suisse. En tant qu'instrument pour la mise en œuvre du Concile Vatican II, le Synode 72 a discuté des options du Concile, telles que les offices ecclésiastiques dans l'Église locale (LG 33; Paul VI, Ministeria quaedam; Jean-Paul II, Christifedles laici; c.228 CIC 1983). La tradition de codécision des baptisés a été activée. "Quod omnes tangit, ab omnibus tractaristanprobari debet ». Les canonistes ont développé l'état de droit en Europe occidentale. Après de longs débats (Actes $15: 7$ ), ils ont décidé avec le Saint-Esprit. Le Nonce apostolique a permis aux laïcs (femmes) de participer au Synode.

Mots-clés: participants aux synodes d'Églises locales, bureaux locaux d'église du clergé séculier et des diacres, démocratie, état de droit, tradition juridique occidentale, femmes dans le processus de prise de décision

AdRIAN LORETAN-SALADIN

\section{Sinodalità svizzera dopo il Concilio Vaticano II}

\section{Sommario}

Il Sinodo'72 è un processo di sette sinodi di Chiese locali in Svizzera. Come strumento per l'attuazione del Concilio Vaticano II, il Sinodo 72 ha discusso opzioni del Concilio, come ad esempio gli uffici ecclesiastici nella Chiesa locale (LG 33; Paolo VI, Ministeria quaedam; Giovanni Paolo II, Christifedles laici; c. 228 CIC 1983). Si attivava la tradizione della codecisione dei battezzati. "Quod omnes tangit, ab omnibus tractaristanprobari debet». I canonici hanno approfondito la questione dello stato di diritto nell'Europa occidentale. Dopo un lungo dibattito (Atti 15: 7), decisero insieme allo Spirito Santo. Il Nunzio Apostolico ha permesso la partecipazione al Sinodo dei laici (donne).

Parole chiave: partecipanti ai sinodi della chiesa locale, uffici ecclesiastici locali del clero secolare e dei diaconi, democrazia, stato di diritto, tradizione giuridica occidentale, donne nel processo decisionale 